\title{
A Working Paper on Procurement Anti-corruption in Yemen
}

\author{
Dr. Mohammed Ahmad Ali Thabit \\ Lecturer in Business Administration Department \\ Associate Professor of Construction Project Management \\ Department of Architecture, Faculty of Engineering \\ University of Aden and Member of the BOD of HATC \\ Republic of Yemen
}

\begin{abstract}
Yemen today faces a lot of challenges as war, poverty, terrorism and corruption. Corruption in Procurement in Yemen, as in any other country also, is one of the most important causes of the un-efficient delivery of public services and the waste of public funds. Therefore, Procurement Anti-Corruption plays a key role in the development of the national economy in Yemen.

Abuse of power in procurement, Bribery and kickbacks, Nepotism and favoritism, Collusion and bid rigging, and Misuse of public fund are some of the various manifestation of the corruption in procurement.

This paper describes the procurement practice in Yemen and the constraints facing the fight against corruption in the procurement. The Enhancing of the procurement system in Yemen becomes now a priority to avoid corruption on the one hand, and to improve the infrastructure services of the people in Yemen, on the other. For a sustainable and Corruption-free procurement, HATC strategies on the short and medium term are addressed at the end of the paper and also some key recommendations.
\end{abstract}

Keywords: Yemen, Procurement, Corruption.

\section{Introduction}

Yemen is a country located at the south eastern end of the Arabian Peninsula with $530000 \mathrm{~km}^{2}$ area, includes 21 Governorates, sub-divided in 333 districts, and its population is estimated at 28 million today.

In early 2006, the Government of Yemen, with the support of international development partners, launched a set of ambitious and interconnected reform measures promoting good governance called the National Reform Agenda (NRA). Triggers for the NRA were the local needs to combat corruption, optimize the use of the limited national resources, improve the life of the citizens, and respond to the frequent alerts reported by the developments partners to improve the public procurement system. Findings of the WB report on "Yemen Country Procurement Assessment Report" completed on December 21, 2000, showed that several gabs exist in the system including Legislative, institutional, and transparency \& integrity frameworks, in addition to contradictions with the World Bank's Guidelines.

\footnotetext{
* This article was submitted in May 2017, accepted for publishing in October 2017 and published on December 2019.

(C) Arab Administrative Development Organization- League of Arab States, 2019, pp 251-264، ～DOI: 10.21608/aja.2019.66952
} 
The Country Profile for Yemen is based on data from the Enterprise Surveys conducted by the World Bank.[16] The benchmarks include the averages for the group of countries in Middle East \& North Africa and the Yemen income group.

Below is a snapshot of the biggest business environment obstacles as perceived by firms. The graph presents the top 10 constraints as identified by firms in Yemen benchmarked against the regional average.

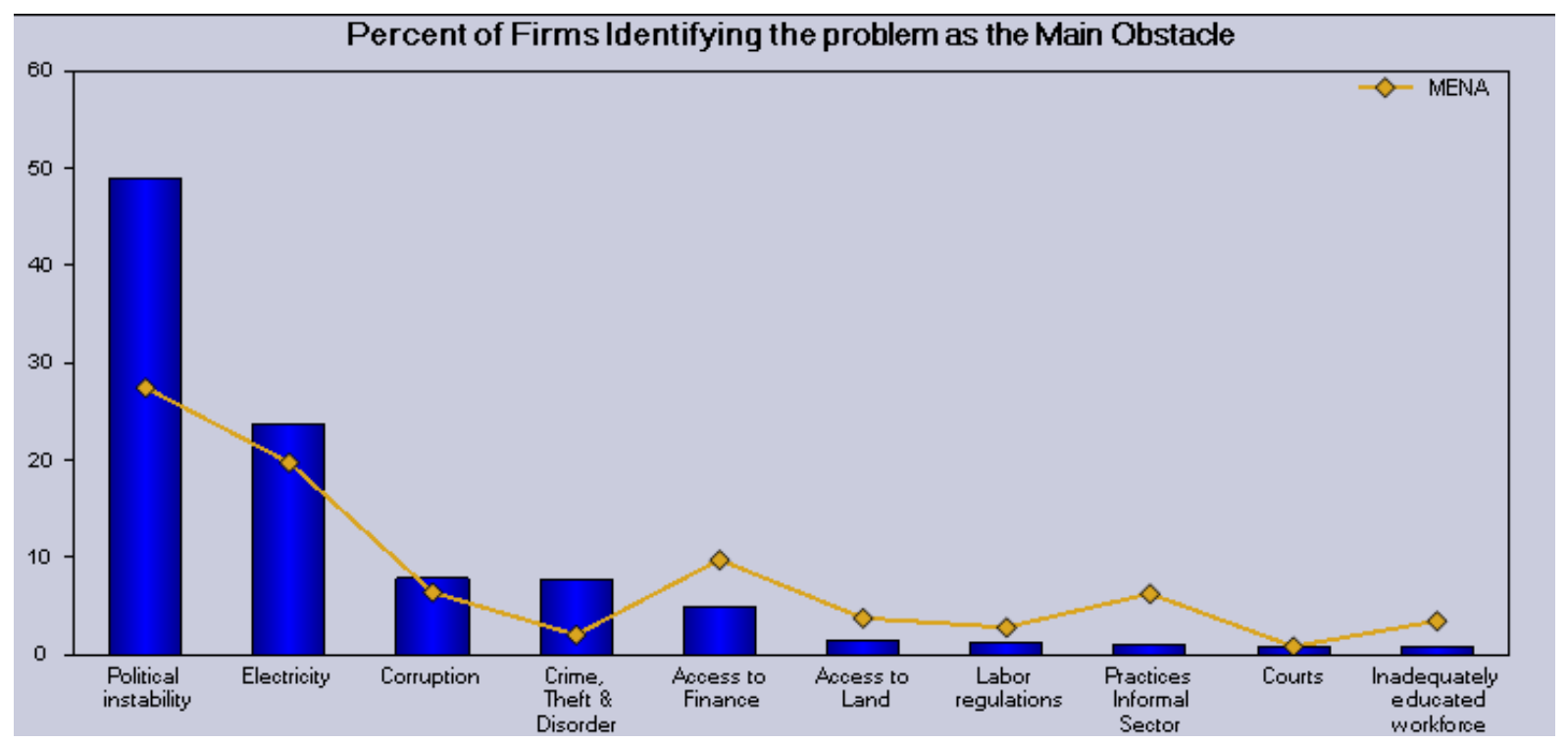

\section{Corruption in Public Procurement}

Evidence of public procurement dates from the period between 2400 and 2800 B.C. in Syria and 800 B.C. in China and Greece. [12]

In fact, Public procurement is estimated to account for 15-30 percent of the gross domestic Product (GDP) of many countries. Various studies suggest that an average of 10-25 percent of a public contract's value may be lost to corruption.[14]

Every year an estimated average of US\$ 9.5 trillion of public money is spent by governments through public procurement.[2]

The European Commission calculated that in the Member States around €120 billion

(Around US\$163 billion) is lost each year to corruption. [13]

According to Organization for Economic Co-operation and Development (OECD) estimates, money drained through corruption amounts to between 20 per cent and 25 per cent of the procurement budget, that is around US\$ 2 trillion annually.[7]

Generally, as much as 20-25 percent of public spending on procurement is lost due to leakages and malpractices in developing countries.[4]

The world Bank has estimated that roughly \$1.5 Trillion in public contract awards are influenced by corruption.[8] 
Researchers at the World Bank estimate that worldwide bribery totals at least \$1 trillion per year, just over $3 \%$ of world income in 2002.[10]

During the period from 1995 to 2001 the Republic of Yemen has lost an estimated 41 billion Yemeni Riyals, approximately US \$32 million, and more than several millions of hard currency. Therefore, waste money represents $10 \%$ of GDP in 1995.[19]

Report of the Yemeni Journalists' organization against Corruption states that the value of purchase made in violation of the law of Tenders and financial laws during the three years (2006-2008) has reached more than two trillion Yemeni Riyals. [18]

The cost of corruption in public contracting is not only measured by money lost. Corruption distorts competition, can reduce the quality, sustainability and safety of public projects and purchases, and reduce the likelihood that the goods and services purchased really meet the public's needs. When procurement is corrupted by private interests and not directed by the public good, trust in governments is eroded.[13]

According to my experiences, [8] and [15], corruption can exist in one or more of following procurement cycles.

\begin{tabular}{|c|c|}
\hline procurement cycle & Corruption risk \\
\hline \multirow[t]{11}{*}{ Pre-tender stage } & 1. Needs assessment \\
\hline & 2. Categories of Procurement \\
\hline & 3. $\quad$ Budgeting \\
\hline & 4. Structuring of the bidding Process \\
\hline & 4.1.Tender Documents \\
\hline & 4.2. Procurement Procedure \\
\hline & 4.3. Time Limits \\
\hline & 4.4. Contractor Qualification \\
\hline & 4.5. Minimum and Selection Criteria \\
\hline & 4.6. Technical Specifications \\
\hline & 4.7. Award Criteria \\
\hline \multirow[t]{5}{*}{ Tender Stage } & 1. Public Notice \\
\hline & 2. Requests for Clarification \\
\hline & 3. $\quad$ Public Bid Opening \\
\hline & 4. Evaluation of Tenderers and Tenders \\
\hline & 5. Publication of intended Contract award and awarded Contract \\
\hline Post- tender Stage & Implementation and Administration of the Contract \\
\hline
\end{tabular}

The chart below illustrates what might be called the "vicious circle" of corrupt procurement practices. The chart distinguishes action taken on the government, contracting agency, side and action by competitors for government contracts. It also distinguishes practices which occur at the pre-award stage of procurement from behavior after award, while a contract is being executed.[15]

Schooner (2002) had addressed nine goals frequently identified for government procurement systems: (1) competition; (2) integrity; (3) transparency; (4) efficiency; (6) customer satisfaction; (7), best value; (8) wealth distribution; (9) risk avoidance; and (10) uniformity, and risk avoidance. [11] 
Empirically, application of procurement rules appears to reduce prices by around 30 percent because effective public sector procurement contract system hinges on a desired degree of

transparency, integrity, competence, competition, and value for money.[1]

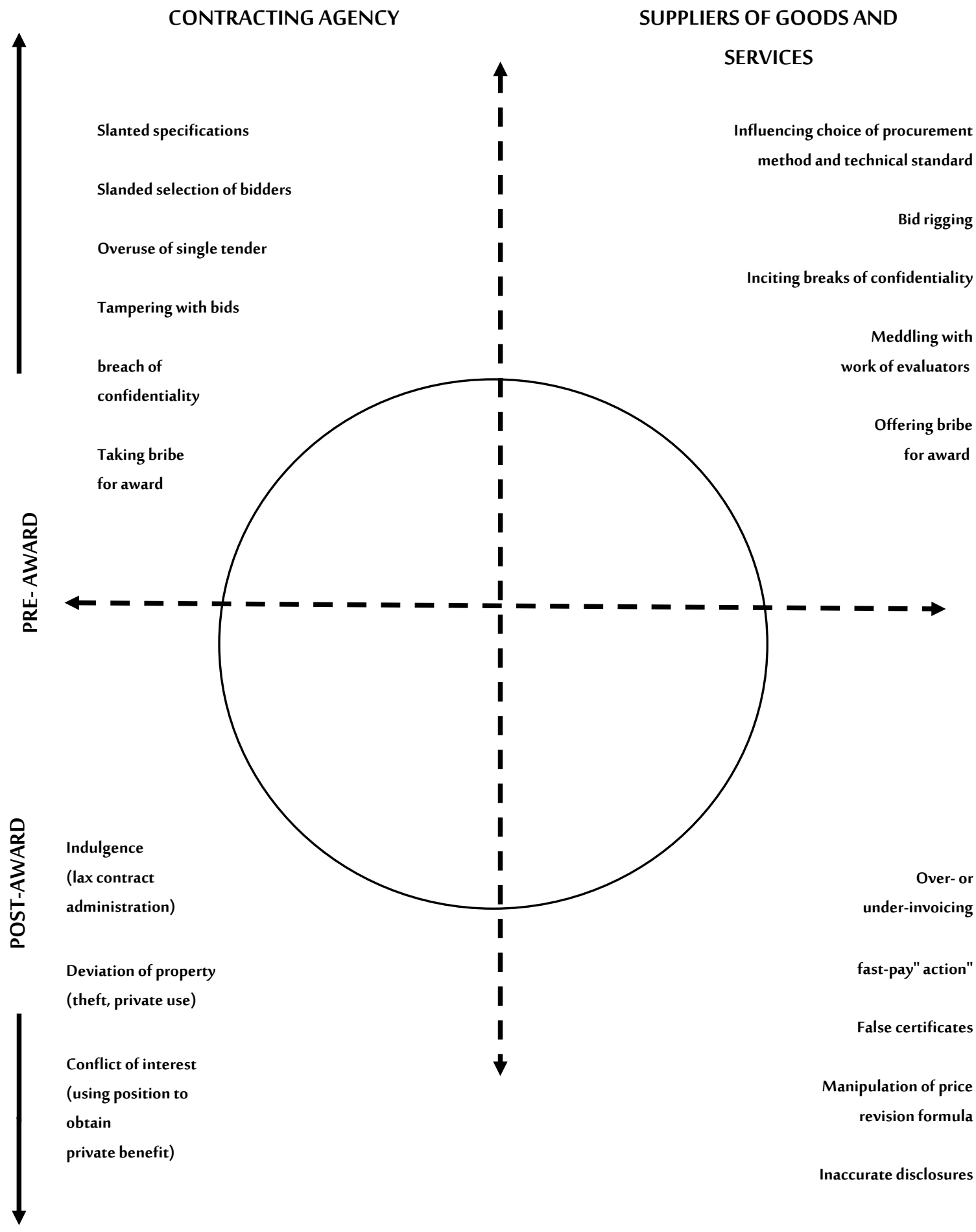

Figure (1) The Vicious Circle of Corruption in Public Procurement 


\section{Legal Infrastructure, Institutional and Administrative Structure}

The UNCITRAL Model Law, the World Trade Organization (WTO) Government Procurement Agreement (GPA) and the European Union (EU) Public Procurement Directives (EU Directives) are most important from a legislative perspective, as they are the models most often examined when drafting procurement legislation.[1] The UNCITRAL Model Law on Public Procurement reflects International best practice and is design to intend as a reference tool for policy maker and legislation on procurement of goods, works and services. The Model law is based on six main objectives as follow:

- $\quad$ Achieving economic and efficiency.

- Wide participation.

- Maximize competition.

- Ensure equal and fair treatment.

- Assure integrity, fairness and public confidence in procurement process.

- $\quad$ Promote transparency.

Laws

To avoid those above mentioned gaps in former law No. (3) for 1997 on Purchase, improve the procurement system, and to fight corruption in procurement and in other fields, Yemen has issued a number of legislations. The most relating and important laws to procurement and anti-corruption are as followings: 1- Law No. (23) Of 2007 on Tenders, Auctions \& Government Storehouses:

This new Law was issued according to UNCITRAL principles (international procedures) Instead of an old one. The article 3 of the Law mentioned its 6 objectives. The "Protection of public funds, maintaining the state's property and assets and fighting corruption in bids and Auctions" was the first objective. The law mentioned also the following five objectives:

- Fairness and equality in treatment of bidders and auctions.

- Integrity, Transparency and accountability, and streamlining and defining procedures in bids, procurement and storehouses.

- Economic effectiveness in bid and auction activities.

- Effective supervision and monitoring of bid, procurement and storehouse activities to safeguard and protect public funds and interest.

- Encouraging Contractors, Suppliers, and Consultants to develop their performance professionally and economically.

\section{2- Anti-corruption Law No (39) for 2006:}

This Law has considered fraud and manipulating in bidding and auctions or any form of government contracts and other 11 actions as Corruption crimes in its chapter four, section one, Article (30).

\section{3- Other Related Laws:}

The most of these Laws touched the corruption with its various forms and ways to combat and reduce it. The above mentioned two laws is strengthened by the following laws that focus on enhancing integrity and transparency: 
a- Law No. (30) for 2006 on Financial Statement Disclosure;

b- Law No. (39) for 1992 On Establishing The Central Organization for Control and Auditing (COCA);

c- Law No. (8) for 1990 on Public Finance and its amendments in law No. (50) for the year 1999;

d- Law No. 47 of 2005 on the ratification of the United Nations Convention on Corruption.

e- Law No. (1) for 2010 on Combating Money Laundering and Financing Terrorism;

f- Law No. (13) for 2012 on Right to Access for Information;

g- Law No. (22) for 1992 on Arbitration- Amendment.

h- Law No. (19) for 1999 on Encourage Competition and Prevent Monopoly and Commercial Fraud.

i- Law No. (4) for 2001 On Local Authorities;

j- Law No. (31) for 2009 on Careers rotation;

k- Draft of the Public Private Partnership (PPP) Law was prepared in 2013 through a Yemeni national committee, which the researcher was one of them.

I- Draft of the Recovery of Stolen and Proceeds funds of corruption crimes was prepared, and now is in discussions.

\section{By-laws, Regulations and Relating Documents}

By-laws, regulations and relating documents were issued complement, clarify, and explain in detail how to implement the issues raised in the laws. In Yemen the Cabinet of Ministers has the mandated to issue the regulations. Following by-laws, regulations and relating documents were issued:

a- Presidential Decree No. (19) For the year 2010 on the executive regulations of anti-corruption Law No. (39) For the Year 2006.

b- Prime Minister's Resolution No (53) of the Year 2009 of the Executive Regulations of Law No (23) for the Year 2007, Concerning Tenders, Auctions and Government Storehouses.

c- Prime Minister's Resolution No (263) of the Year 2008 on the Debarment of violators of contractors, suppliers and consultants.

d- The Procurement Manuals and the Standard Bidding Documents (SBDs) developed under the supervision of the World Bank. Approved in 2006, and already updated and endorsed by the Council of Ministers in year 2010. These are as following:

- Contract-consult-services-Amount.

- Contract-consult-services-time.

- Manual-consult-services.

- Manual-works-goods.

- SBD-consult-services- Amount.

- SBD- consult-services-time.

- SBD-goods-n.

- SBD-goods-s.

- SBD-works-n.

e- By-laws and Regulations of other Laws mentioned before. 


\section{Institutional and Administrative Structure}

According to the 2007 Tender Law and its relevant regulation, the Government established some bodies which are involved in the procurement such as:

\section{1- The High Authority for Tender Control (HATC)}

The HATC is issued by the Presidential Decree 17 of 2009, published on August 17, as the key public procurement oversight institution. The HATC is the public procurement policy agency which acting as the supreme review authority for complaints submitted by bidders.

\section{2- The High Tender Board (HTB)}

HTB is a key public procurement monitoring body approves high-value tenders (above YER 250 million), produces and updates standard bidding documents and guides, and provides training for procurement specialists.

\section{3- Other Tender Boards}

a- Tender Boards in Ministries (TB): The Tender Board of each Ministry is responsible for reviewing and approving tenders for public services, works and goods according to the 2007 Tender Law and the 2009 Executive Regulations.

b- Sub-Tender Boards (STB): There are two levels of sub- Tender Boards under the Local Authority Law of 2000: the governorates and the districts.

\section{Other Relating HATC Partners}

HATC has a good relationship with the organizations which work in the Anti-corruption. The organizations (HATC, SNACC and COCA) represent the anti- corruption system in Yemen. The roles and responsibilities differ from one organization to another while they share the responsibility for monitoring the public procurement. The roles and responsibilities of the supervision and monitoring organization are complementary to each other. Through some interference may exist, it does not affect the integration, and an effort to unify and align the interpretation of law and regulations provisions is underway.

Due to the integrated roles and responsibilities of these organizations in the public procurement, there is a coordination and mutual cooperation. Several meeting were organized to discuss the mutual concern problems and come up with unified understanding of the Law interpretations.

There are also other relating partners which work closely with HATC in the matters of development, procurement and anti-corruption.

1- The Supreme National Authority for Combating Corruption (SNACC). SNACC was created by the 2006 Anti-Corruption Law. Its mandate includes collaboration with civil society in the fight against corruption, investigating complaints of corruption, working with the media on public awareness raising about corruption.

2- The Central Organization for Control and Auditing (COCA): COCA is the independent supreme audit institution responsible for financial control, performance appraisal, and evaluation of the legal and organizational contexts for all administrative units of the state at both the central and local levels, as well as for public and mixed sector units. 
3- The Ministry of Planning and International Cooperation (MOPIC): MOPIC is responsible for the preparation and co-ordination of the Public Investment Program. MOPIC is the government's point of contact with international donors.

4- $\quad$ The Ministry of Finance (MOF): The Ministry of Finance is responsible to Parliament and to Cabinet for formulating national economic policies, managing and collecting national revenues and distributing the government's financial resources.

5- The Civil society: Civil society plays an essential role in monitoring procurement processes to ensure that public procurement is conducted in a transparent, competitive and objective manner. Civil society could act as a "watchdog" or public monitor of government on behalf of all citizens.

6- The Private sector: The private sector in Yemen is playing traditionally an important role in the development of the country. Reforms and new legislations issued by the government will lead to a positive effect in the commend years in enhancing its role.

7- The media: Political stability and freedom of press are all associated with lower corruption.[5] Corruption is a theme for the media. In the press almost we find new cases of corruption. The attention of the media is concentrated mainly on individual representatives of state, politics and economy.

8- The International development partners and donor countries: Multilateral organizations and OECD donors are the major development partners of Yemen; they provide both project and programme aid. These include the World Bank's International Development Association (IDA), the Arabic Fund for Development, the UN agencies, Japan, the Saudi Fund, USAID, the EU, and the Netherlands.

\section{Key Tools to Improve Procurement Anti-corruption}

\section{Integrity and Transparency}

By integrity, we mean to describe rules of conduct for procurement personnel in the government and private industry. Bribery, favoritism, or unethical behavior has no place in a successful procurement system.[9]

By system transparency, we mean a system employs procedures by which offerors and contractors (and even the public at large) ensure that government business is conducted in an impartial and open manner.[3]

Integrity and transparency gain today in the world and Yemen also a one device for Procurement Anti-corruption. The Yemeni procurement law appointed Integrity and Transparency in its third objective clear and also in its Executive regulation.

The Code of conduct is Included in a special chapter in the Law, chapter 5, pages from 50 to 55.

Private sector and NGO's awareness campaigns were initiated to ensure support for enhancing the integrity and transparency of the system.

The access to the procurement information is improved through the establishment of web sites for publication of bids/awards (i.e. HATC, HTB, and others.). And all contractor, consultants, suppliers, media, and researchers have the right to access to the Information of HATC and other anti-corruption bodies. 


\section{Complaints}

Complaints are a vital source of information about fraud and corruption in the procurement. Many complaints, while not mentioning the words fraud and corruption, upon investigation often lead to the discovery of such misconduct. For example, a complaint about missing or defective materials could indicate low capacity, but it could also indicate that in exchange for bribes, defective materials were accepted. Complaints can relate to any type of scheme or risk.[3]

A mechanism of bidder's complaints was reviewed and the resolutions are enforced (at three levels, TBs, HATC, Court of Law), decisions are published in HATC web site.

573 complaints were processed since Sep 2009 (Establishment of HATC) till Dec 2016.

103 complaints of them were dismissed, 234 complaints were rejected and 236 complaints accepted and corrective measures were taken.

38 complaints of the 236 complaints accepted were considered crimes and sent to SNACS or Attorney General for other measures to be taken through them.

Finally, efficient complaint mechanisms increase the confidence of private suppliers in the fairness of the procurement process and their willingness to file a complaint.[17]

\section{PMIS System}

The procurement management information system (PMIS) is an electronic information network system that manages procurement and tenders in various government entities subjected to the new Procurement law. HATC has started the pilot phase of the project with 8 procurement entities. PMIS has to achieve the following Objectives:

1- Improving planning, executing and monitoring the public procurement.

2- Provide Accurate \& timely Management Information for the decision makers.

3- Improving the transparency, integrity, and economic efficiency in public procurement.

4- Improve knowledge of expenditures on commodities across all Government organizations.

The PMIS system is a first step to use e-procurement in the future.

\section{Activities Conducted by HATC}

HATC has many efforts, achievements and successes that culminated in its work since its establishment in 2009.Generally that were in overseeing all tenders committees in Yemen and directing them to ensure the implementation of public procurement procedures in accordance with the law and its executive regulations. It is also necessary to mention in table (1) some important activities was conducted by HATC, that had lead to best procurement practice by the tenders committees. 
Table No. (1)

Important Activities Conducted by HATC

\begin{tabular}{ll}
\hline \multicolumn{1}{c}{ Legislative/ Policies } & \multicolumn{1}{c}{ Monitoring and Supervision of TBs } \\
\hline $\begin{array}{l}\text { Procurement Regulation for Oil Exploration and } \\
\text { Production Authority. }\end{array}$ & Ensure correct formation of TBs. \\
\hline Review of the Oil Production Sharing Agreements. & $\begin{array}{l}\text { Review procurement plans and compare with } \\
\text { budget Allocations. }\end{array}$ \\
\hline Advertising services Regulation & Review procurement reports. \\
\hline Approving the time -bounded procurement process & Follow up Advertisements, correct violations, and \\
Mechanism. & establish complete data base. \\
\hline Review of the debarment Regulations. & Follow up topics related to procurement in the local \\
\hline Review of Procurement Law and By-law. & press. \\
\hline Draft legislation for establishing a temporary country & Refer cases to SNACC. \\
Procurement Portal through HATC web site. & \\
\hline Prepare the draft tender committees" Incentive & Follow up the short listing of consultants, \\
Regulations. & prequalified contractors and bidders of goods. \\
\hline Preparation of the draft Construction Supervision Staff & Conducting inspection visits to tender entities. \\
Incentives Regulations. & \\
\hline
\end{tabular}

\section{Constraints}

HATC and other Anti-corruption organizations face many constraints and obstacles encountered in their work. The most important are:

1- Existence of some legislation that prevents or limits the trial of the high ranking officials. One of them is Law No. (6) For 1995 on Indictment and Trial of the Occupants of the Officials in Functions of the Supreme Executive Authority for their actions.

2- Title and some clauses of the present procurement law lead to ambiguity and lack of understanding of some of the functions in law.

3- Lack of competent staff with adequate procurement knowledge.

4- Long delays in procurement process in both bidding and contract implementation (legal, institutional, procurement staff).

5- Poor filing and documentation for procurement activities.

6- Poor procurement planning and contract management activities.

7- Scarcity of data for pricing which leads for overpricing in many instances.

8- Weak private sector/NGOs institutions. 


\section{HATC Strategy for Improving the System}

It is necessary to remove those restrictions and obstacles in order to develop the work of the HATC and other Anti-corruption organizations. HATC has suggested some activities, to be conducted on the shortterm and medium-term.

Table No. (2)

Activities to be Conducted on the Short-term and Medium-term.

\begin{tabular}{|c|c|}
\hline Short Term & Medium Term \\
\hline $\begin{array}{l}\text { Repeal the legislation that prevents or limit the Indictment } \\
\text { and trial of high rank officials. }\end{array}$ & $\begin{array}{l}\text { Harmonization of the Laws, By-laws, and } \\
\text { the supervision and monitoring institutions } \\
\text { responsibilities and mandates to avoid duplication } \\
\text { of roles. }\end{array}$ \\
\hline $\begin{array}{l}\text { Approving the amendments of the present procurement } \\
\text { law, as change of Title and other articles. }\end{array}$ & $\begin{array}{l}\text { Improve PE's capabilities in the remote districts } \\
\text { (i.e. staff training, provision of equipment, } \\
\text { communication facilities.etc.) To ensure readiness } \\
\text { for PMIS. }\end{array}$ \\
\hline $\begin{array}{l}\text { Complete the establishment of the National Procurement } \\
\text { Portal and ensure dissipation of information to the private } \\
\text { sector, NGO's and public to ensure their support in } \\
\text { fighting corruption in the procurement. }\end{array}$ & $\begin{array}{l}\text { Prepare a comprehensive capacity building and } \\
\text { training plan for both public and private sector } \\
\text { institutions. }\end{array}$ \\
\hline $\begin{array}{l}\text { Training of supervision and monitoring entities staff for } \\
\text { conducting reviews and audits. }\end{array}$ & $\begin{array}{l}\text { Conduct periodic procurement system assessment } \\
\text { (6-12 months) to identify gabs and take the } \\
\text { necessary remedial actions. }\end{array}$ \\
\hline $\begin{array}{l}\text { Improve the procurement training manual for } \\
\text { procurement officers. }\end{array}$ & $\begin{array}{l}\text { Establish guidelines for Impact Assessment to } \\
\text { measure the effectiveness of various policies and } \\
\text { improve performance. }\end{array}$ \\
\hline Training of Trainers. & $\begin{array}{l}\text { Improve public access to internet to improve } \\
\text { government accountability and transparency. }\end{array}$ \\
\hline Training of PE's procurement staff. & $\begin{array}{l}\text { Simplify the procurement process while } \\
\text { maintaining the integrity and transparency of the } \\
\text { system. }\end{array}$ \\
\hline $\begin{array}{l}\text { Complete the standard technical specifications and } \\
\text { supervision manuals for buildings, roads, and water \& } \\
\text { sanitation projects. }\end{array}$ & $\begin{array}{l}\text { Improve the private sector and NGO's awareness } \\
\text { in procurement policies to improve transparency } \\
\text { and integrity (establish relevant fora, media } \\
\text { coverage ...etc.) }\end{array}$ \\
\hline $\begin{array}{l}\text { Complete the standard technical specification for } \\
\text { commodities. }\end{array}$ & $\begin{array}{l}\text { Complete the remaining phases of the PMIS and } \\
\text { link all government entities in the central and local } \\
\text { level. }\end{array}$ \\
\hline
\end{tabular}




\section{Short Term}

Improve the private sector and NGO's awareness in procurement policies to improve transparency and integrity (establish relevant fora, media coverage ...etc.).
Medium Term

Ensure the proper procurement planning and monitoring. Link the (AFMIS, LGMIS and PMIS). Develop web based Price Indices for construction materials and commodities.

Study the feasibility of developing the web based procurement system to e-procurement system. proper procurement planning and monitoring (AFMIS and PMIS).

Complete the proposed Law and By-Law amendment to Conduct a comprehensive procurement system improve system efficiency. assessment to identify weaknesses of the system as per OECD/DAC methodology.

Improve auditing mechanisms/manuals/compliance checklists (HATC inspection visits manual, compliance Intensify public awareness campaigns through media.

checklists, COCA...)

\section{Conclussion and Key Recommendations}

It is difficult to achieve political and economic stability in Yemen, while corruption is prevailing in all aspects of life in one side. And the Fight against corruption is not only the responsibility of the state, nor is it limited to legislation and enact laws and the formation of bodies, units, and councils to combat corruption, it is a societal issue in which the state participates with citizens and all civil society organizations, on the other side.

I suggest here some key recommendations that may well contribute to the development of initiatives of procurement anti-corruption in Yemen:

1- The fight against corruption needs a strong political will.

2- Development of the relevant procurement, sustainability and anti-corruption legislations.

3- Reform and improve the wages and incentives law in the public service.

4- Encourage the media to expose corruption cases.

5- Encourage the NGOs and the different communities to effective participation.

6- Build a mutually beneficial partnership between Government and the private sector.

7- Encourage and promote the cooperation between the national, Arab, regional and international bodies involved in combating corruption.

8- Strengthen the capacity of the key national oversight institutions (Judiciary, Oversight organizations (SNACC\&COCA) and Procurement (HTB\&HATC), and Private sector as well.

9- Provide greater transparency and accessibility to decisions about public procurement;

10- Link procurement planning to the national budget and Public Investment Program processes. 


\section{References}

- $\quad$ Adegbola, M. F., Akpan, E. E., Eniaiyejuni, B. O., Alagbe, J.K., Kappo, E. E., \& Yunusa, D. A.(2006). The Problem Effective Procurement and Contract Management in the Public Sector, Toppo-Badagry, Lagos, Nigeria: Administrative Staff College of Nigeria.

- Caroline Spruill. (2013). “Open Contracting: Factivists Fighting Procureaucrats” (9 December): www.opencontracting.org/open_contracting_factivists_fighting_procureaucrats.

- Christopher R. Yukins. (2010). A Versatile Prism: Assessing Procurement Law through the Principal-Agent Model, the George Washington University Law School, Public Control Law Journal, Vol.40, No.1, fall 2010, http://ssrn.com/abstract=1776295.

- $\quad$ Falvey, R., Chimia, A. L., Morrissey, O. \& Zgovu, E. (2007). Competition Policy and Public Procurement in Development in Developing Countries, (Centre for Research in Economic Development and International Trade Research Paper No. 08/07). [Online], Available at www.nottingham.ac.uk/economics/credit.

- $\quad$ Lederman, D., Loayza, N., \& Soares, R. R. (2005). “Accountability and Corruption: Political Institutions Matter." Economics \& Politics, 17 (1): 1-35.

- $\quad$ Matechak, J. P., Fighting Corruption in Public Procurement, CIPE, 4 p.

- OECD. (2013). Implementing the OCED Principles for Integrity in Public Procurement, November, www.oecd-ilibrary.org/governace/implementing-the-oecd-principles-for-integrity-in-public-procurement/Htm.

- Passas, Nikos. (2007). Corruption in the Procurement Process/Outsourcing Government Functions: Issues, Case Studies, Implications, Institute for Fraud Prevention, Northeast University Boston, 33p.

- $\quad$ Rose-Ackerman, Susan. (1999). Corruption and Government: Causes: Consequences and Reform. Cambridge.

- Rose-Ackerman. (2004). The Challenge of Poor Governance and Corruption. Copenhagen Consensus, $64 \mathrm{p}$.

- Steven L. Schooner. (2002). Desiderata: Objectives for a System of Government Contract Law, http:/papers.ssrn.com/abstract=304620.

- $\quad$ Thai, K. V.(2001). "Public Procurement Re-examined", Journal of Public Procurement, 1(1): 9-50.

- Transparency International. (2014). Curbing Corruption in Public Procurement: A Practical Guide. 40 p.

- $\quad$ UNDOC, United Nations. (2013). Guidebook on Anti-Corruption in Public Procurement and the Management of Public Finances, New York, $68 \mathrm{p}$.

- Westring, G. and Jadoun, G. (1996). Public Procurement Manual, Turin, 301 P.

- World Bank, European Bank, European Investment Bank. (2013). Enterprise Surveys: YEMEN 2013, 15 P, http://www.enterprisesurveys.org.

- World Bank Group. (2017). Flagship Report, Doing Business 2017: Equal Opportunity for All, $14^{\text {th }}$ Edition.

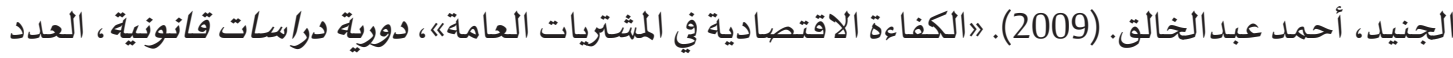

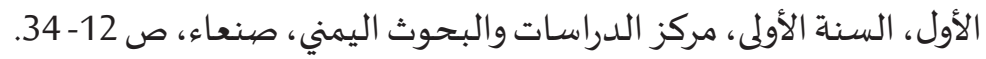

السعيدي، محمد يحي. (2004). الفساد والتنمية: أثر الفساد الإداري والمالي على التنمية المستـدامة هورة ، صنعاء. 
